\title{
Sustainable Transport as a Key Pillar to Community Resilience During the COVID-19 Pandemic
}

\author{
Arturo Ardila-Gomez
}

\begin{abstract}
As cities gradually exit COVID-19 quarantines, some are suggesting that public transport might increase contagion risk and that private cars should be considered the only safe alternative. This view, however, is based on perception rather than facts. Moreover, promoting widespread car use could actually impede recovery and come with a host of negative side effects, especially for the poor. This chapter uses the Three Cs framework-avoid closed and crowded spaces, and closed contact situations and in particular their overlap - to understand how sustainable transport can be resilient to the pandemic. To minimize the three Cs while preserving the economy the ideal is to have people work from home which applies only to workers who tele-commute. Yet for first responders, blue-collar, and informal workers getting to work is essential for generating income. Sustainable transport can provide efficient, dependable mobility that connects people to opportunities and be COVID-safe during this pandemic.
\end{abstract}

\subsection{Introduction}

As cities gradually exit COVID-19 quarantines and reopen their economies, some observers are suggesting that public transport might increase contagion risk [1] and that private cars [2] should be considered the only safe alternative. However, this stance is based on perception rather than facts. In addition, promoting widespread car use could actually impede recovery and come with a host of negative side effects, especially for the poor.

In this observation chapter I explain why sustainable transport - public transport, walking, and biking - must become an integral part of our response to the pandemic, and how we can make this happen in a safe, resilient way.

\subsubsection{We Need to Keep People and Economies Moving}

The International Labor Organization estimates that a whopping 1.6 billion people are at risk of losing their livelihoods [3]. Many of them are informal workers who do not have access to unemployment benefits or any other kind of social safety nets. Some 39 million people have already lost their jobs in the United States [4]. There is growing concern that many jobs lost to the pandemic will vanish forever [5], raising some significant questions about the future of the labor market, particularly in cities.

Furthermore, the ILO estimates that, globally, "more than 436 million enterprises [3] face high 
risks of serious disruption." Related, up to 580 million people could fall into poverty [6], as estimated by the United Nations University. There is also a high probability that the health crisis may contribute to a hunger pandemic [7] could push another 130 million people to the brink of starvation.

These numbers show how quarantine and shelter-at-home can hurt millions of people, particularly the poor. Now, imagine if these losses were permanent and the urban labor market collapsed. Poverty would skyrocket, middle classes would shrink, and tax revenue would plummet. To avoid this scenario, countries are anxious to reignite their economies while minimizing contagion risk, which remains a major preoccupation worldwide. Transport will be a key piece of the equation: we must find ways to connect people to jobs, and to connect them as safely and sustainably as possible. For example, 60 percent of the world's employed population work in the informal market [8]. Informally employed people typically must travel outside their homes to generate income [9].

\subsection{Sustainable Transport and the Call for a Green Recovery}

As the world grapples with the pandemic and its economic fallout, we cannot forget about the climate crisis that has been looming over the last few decades. While the measures to lower the spread of the virus have temporarily reduced greenhouse gas emissions [10], atmospheric carbon dioxide levels are the highest in human history [11]. Just in 2020, northern Siberia-above the Arctic Circle - experienced record-high temperatures [12] that can melt the permafrost and release even more GHG (greenhouse gas) into the atmosphere.

Clearly, decisionmakers at all levels must work toward a green recovery model that will help address the ongoing health, economic, and climate emergencies simultaneously. Moving toward sustainable transport will be a key part of that process: the transport sector already accounts for a quarter of energy-related emissions, and that number is poised to grow [13] much higher over the next decade. Low-carbon transport can significantly reduce overall emissions, and, concurrently, will help us build more competitive, more inclusive communities -and be COVID-safe. Transport is also key for community resilience, understood as the "measure of the sustained ability of a community to utilize available to respond, withstand, and recover from adverse situations," (RAND Corporation. N.d.) Sustainable transport is more resilient because it embeds redundancy: many buses provide service, bicycles and pedestrians can circumvent many obstacles. If the solution to the pandemic is to provide every adult in the planet with a car, then resiliency will go down because of the resulting gridlock. Worse, a planet with six billion cars will be very warm due to the huge cradle to grave and well to wheels emissions, regardless of the engine technology.

\subsubsection{The Three Cs: Avoid Closed, Crowded, Close-Contact Situations}

What exactly should sustainable transport look like in the context of COVID-19? What are the transport modes and solutions we should prioritize? And, importantly, how should we adapt existing systems to minimize health risks?

To answer this, I refer to the Three Cs framework: Closed spaces, Crowded spaces, and Close contact situations. According to the framework, the three Cs can drastically increase the risk of spreading the coronavirus, in particular where they overlap [14]. Japan developed this framework to help it contain the pandemic - quite successfully [15]

\subsubsection{Managing Transport Demand Through Home-Based Work}

The best way to minimize the three Cs while preserving the economy is to have people work from home - a situation that applies mostly to workers with access to digital technology. These workers - myself included - can hold virtual meetings, continue to read, and reply to emails, and can even make coffee and cook food at home. For a COVID-safe restart of economic activities, whoever can work from home should continue to do so: this will reduce transport demand and 
allow people who do need to travel to achieve proper physical distancing inside buses or metros, particularly during peak hours [16].

Whether home-based work is temporary or permanent is something that only the future will tell. But it is safe to say that the pandemic will have a lasting and dramatic impact on the way we manage office space [17]. However, it is important to note that not all workers are coping well with home-based work, as indicated by the troubling increase in domestic violence ([18] and [19]), stress [20], and depression [21].

\subsection{Providing Safe Mobility to Those Who Need It}

Yet home-based work is possible not only because of technology, but also because of the countless formal and informal workers who leave their homes every morning to keep supply chains running, deliver packages, and restock the shelves of our local markets. Add first responders who must also travel to work in order to keep us safe and healthy.

For those essential workers, the ability to get around is as important as ever - without a way to reach their jobs, most of them would likely lose their income and have no way to put food on the table. In the next sections, I analyze how we can use sustainable transport to provide safe, green, and efficient mobility for those who need it most, both during and after the pandemic. We will focus on public transport first, and then explore the potential of cycling and walking.

\subsubsection{Safe Operation of Public Transport During a Pandemic}

Many of those who must continue commuting rely on public transport systems, which are uniquely positioned to carry large volumes of passengers through urban areas. Even during a pandemic, public transport remains the backbone of sustainable mobility and essential to economic recovery.

There is growing evidence that public transport riders do not face higher infection risk than anyone else [22, 23]. While Hong Kong relies heavily on mass transit, it has registered few cases even as its mass transit system continues to operate [24]. Japan is also highly dependent on transit, yet researchers "did not trace any [infection] clusters to Japan's notoriously packed commuter trains... Riders are usually alone and not talking to other passengers. And lately, they are all wearing masks," [25]. A study in France found that of the 150 infection clusters that appeared after reopening the economy, none could be traced back to public transport [26]. Several authors rapidly and convincingly debunked attempts to blame the subway in New Your City for spreading the virus $[27,28]$. For example, Manhattan had the highest density of subway lines but the lowest incidence of COVID-19 cases [29]. In contrast, areas with higher car use had higher contagion rates - some researchers found that it was cars that seeded the epidemic [30].

For the sake of public health, economic recovery, and environmental sustainability, we must keep the momentum going to preserve the appeal of public transport. As long as the virus is here, transport providers must adapt their operations to minimize the overlap of the three Cs: Closed and Crowded spaces, and Close contact situations. We need COVID-safe transit systems for staff and passengers.

Many transport systems have adopted stricter cleaning protocols with anti-viral chemicals or simply with soap and water because the virus "is no match for plain old soap [31]." Still, touching a surface such as a handle or a bar is not believed to be the primary way for the virus to spread [32]. Proper ventilation is critical ([23] and [33]). Transport companies should instruct their drivers to open windows systematically or keep the air-conditioning on. In Japan, for example, trains operate with the windows open to ensure proper ventilation [34]. However, the air conditioning cannot be in recirculation mode because air must circulate within the space [35] to prevent contagion.

As person-to-person [32] is the primary transmission means, then public transport users must do their part. They must not touch their faces [36], wear masks [37] — one of the most effective ways to prevent transmission [38] — and wash their hands with soap and water before and after using public transport [32]. 
Notice that this advice applies to everyone, not just public transport riders [32]. Indeed, car drivers should also wash their hands before and after using their private cars. The same goes for cyclists, who can sneeze or cough while riding their bike.

The proper physical distancing between riders is another critical requirement. The World Health Organization recommends people stay at least 1 meter [39] to minimize transmission risk. Masks could help reduce this distance [40] and are effective at preventing the spread of germs in public transport [41]. Still, there is a need to reduce occupancy rates and avoid crowding on transit vehicles. Public transport and particularly mass transit cannot operate initially at high occupancy rates due to regulations to reduce the risk of contagion. To make this possible, countries around the world have temporarily capped transit capacity: Colombia, for instance, announced that public transport can use only $35 \%$ of its capacity [42], while the UK (United Kingdom) set an even lower limit of just $10 \%$ [43]. Governments can increase these caps as the epidemic evolves [44], and scientists [45] gain knowledge on key epidemiological parameters [46]. Indeed, by September 2020 as the pandemic diminished, the Colombian government increased the maximum occupancy of mass transit to $50 \%$ by requiring improved ventilation and cleaning protocols [47].

\subsubsection{Adapting Infrastructure and Resources}

If cities are to decrease passenger density on public transport vehicles, they need to keep frequent service, which requires predictable speeds and traffic conditions. Easy to say but challenging to implement - especially in developing countries, where residents own fewer cars, but, paradoxically, tend to experience higher congestion levels [48]. The solution: "pop-up bus lanes" or bus priority lanes -implemented of course with proper road safety considerations [49] and proper traffic management measures. The New York Metropolitan Transit Authority, for example, has requested $97 \mathrm{~km}$ of new bus lanes in response to the pandemic [50].

But despite the best efforts of professionals across the sector, there is no denying that the COVID-19 crisis has dealt a massive blow to public transport. Demand nosedived almost overnight [51], leading to considerable financial distress for formal and informal public transport operators. The issue is complicated. The bottom line is that, if governments offer subsidies, they must set proper incentives to avoid service reductions and get operators committed to long-term improvements [52].

The current situation could have a profound impact on the way cities approach their transport policy [53], even once the virus subsides. The measures described in this chapter may have been taken hastily in the face of a global public health emergency. Nonetheless, these measures already challenge many deeply-rooted assumptions about urban transport [54]. Think of the space that private cars are supposedly entitled to in comparison to mass transit. Something as simple as a pop-up bus lane lets us envision what a transit-friendly city could look like: a greener, more inclusive place where the road belongs to everyone [55]. People at all income levels could get around quickly and efficiently.

Bolstering public transport will be instrumental if we are serious about putting sustainable mobility at the heart of the "new normal." Communities will be more resilient also because of the redundancy embedded in public transport and the efficient use of scarce resources such as road space. And even though the pandemic has dealt a significant blow to the sector, the lockdowns have also created unexpected opportunities to rethink sustainable transit vs. private cars.

\subsubsection{Biking}

Decisionmakers have quickly realized that bicycles could be a COVID-safe transport for residents to get around. Besides being an open-air form of transport, cycling also makes it easy to enforce physical distancing thanks to each bike's physical footprint and the additional gap that cyclists need to leave between each other to avoid collisions. Notice how bicycles naturally avoid the three Cs that increase the risk of infection, especially when they overlap: closed spaces, crowded spaces, and close-contact situations.

As a result, many cities in both developed and developing countries have been deploying pop-up bike lanes over the last few months, from Paris and London to Berlin, Milan [56], Bogotá, Mexico 
City, Lima [57], and Wuhan. As part of this trend, new design guidelines help local governments implement simple changes to road infrastructure or signage, allowing for the creation of bike lanes at a low cost and in as little as ten days [58].

Although designed as a temporary solution, there is reason to believe that some bike lanes could become permanent. Public opinion is undoubtedly moving in the right direction: $56 \%$ of Londoners "want pavements to be permanently widened to make space for walking and $57 \%$ want to see new cycle lanes created and existing ones broadened" [59]. Further, with the right infrastructure, cycling can carry impressive volumes of passengers. In 2019, $583 \mathrm{~km}$ of permanent bike lanes in Bogotá absorbed 800,000 rides per day - about $6 \%$ of all trips, including walking and motorized [60].

\subsubsection{Walking}

Last but not least, walking is and will be a crucial pillar of urban mobility in developing countries [61], particularly for women [62] and the poor. People walk to access public transport, to shop, or even to commute to work. Walking brings many advantages to cities and their residents. Promoting pedestrian-friendly streets can make travel safer [63], reduce air pollution, improve public space, and create a more inclusive environment for all users [55], including children and people with disabilities.

Because they demand physical activity by users, public transit and active modes like walking or biking are also associated with tangible health benefits such as "lower Body Mass Index, lower waist circumference, less obesity, higher vitamin D, lower cholesterol and lower hepatic inflammation" [64].

The pandemic has made walking even more appealing because it is COVID-safe [65]. Pedestrians on a sidewalk can typically avoid the three Cs that increase the risk of infection. Sidewalks are open spaces. Pedestrians can usually avoid crowding and keep a safe distance of at least 1 meter. Moreover, pedestrians rarely engage strangers walking by, let alone closely. If needed, wearing masks can provide additional protection.

Yet pedestrians face significant challenges, including less-than-perfect infrastructure and competition with other transport modes. In developing countries, for instance, cars frequently park on the sidewalks, making it more challenging for pedestrians - as well as people on wheelchairs and children on strollers - to keep a safe distance.

Cities can take many concrete steps to enforce parking rules and, more generally, to expand the amount of space available to pedestrians. Some are converting road space into "pop-up sidewalks" for the benefit of pedestrians and bicycles [66]. Other cities are even creating "al fresco streets [54]" to allow retail and restaurants to set up shop outdoors. Al fresco streets are an innovative way to avoid the Three Cs and enjoy life in a safe, responsible manner.

These "road diets" [63] will hopefully continue after the pandemic so people everywhere can enjoy the advantages of walking. Road diets work if accompanied by solid traffic management so that car volumes do not lead to gridlock. Many cities are already taking this step and looking at long-term solutions to accommodate pedestrians [53].

\subsubsection{A Window of Opportunity for Sustainable Transport}

The pandemic has forced cities across the globe to take emergency measures that have created a window of opportunity to: Avoid unnecessary travel, Shift toward sustainable transport, and Improve transport infrastructure and services. This "Avoid-Shift-Improve" paradigm [67] is precisely what sustainable transport advocates like myself have been preaching over the last few decades to transform urban mobility. While many decisionmakers used to balk at this approach, the COVID-19 crisis has dramatically changed the transport conversation: people are now clearly seeing the value of sustainable transport, and the idea of reallocating space or resources toward public transit, cycling, and walking has become a lot more acceptable.

The challenge is to keep the momentum going to ensure cities do not move right back to auto-centric development as soon as the virus starts to subside. The transition to sustainable transport could significantly contribute to a green recovery [68] revive urban economies, and create 15 million jobs worldwide [69]. 


\subsection{Conclusions}

Sustainable transport-public transit, walking, and biking - can provide efficient, dependable mobility that connects people to opportunities [70] and be COVID-safe during this pandemic. Transport is indeed what sustains the agglomeration effects [71] that make urban economies so attractive and make the urban labor market work [70]. Sustainable transport is also paramount for achieving community resilience.

But relying on private cars alone will achieve negative results, partly because cars cannot absorb the large volumes of people transiting through busy urban centers every day. Private vehicles will weaken community resilience. Calls for one person per car to be COVID-safe will lead to gridlock and a very warm planet. Sustainable transport is highly relevant in developed and developing countries as this open letter for the European Union states: "As unemployment and lay-offs are expected to rise in the coming months, and family income will be under stress, walking, cycling and public transport will be the most affordable and equitable transport options, and they will be more necessary than ever" [72].

The window of opportunity for sustainable transport has opened. Public transport, biking and walking can create the conditions for a more robust, inclusive, and resilient recovery. Sustainable transport increases community resilience because of the more efficient use of resources, the redundancy embedded in public transport and the ease to navigate obstacles by buses, bicycles and pedestrians. Importantly, these sustainable transport options could also drastically reduce the greenhouse gas footprint of urban mobility - a key priority considering that, despite the temporary dip in emissions [10] induced by the pandemic, atmospheric carbon dioxide levels are at their highest in human history [11]. Promoters of sustainable transport need to become champions to implement sustainable transport and achieve a green recovery while also building a key pillar to community resilience.

\section{References}

[1] Rachel Schraer. Coronavirus: What's the risk on transport? BBC News, 2020. URL https://www.bbc.com/ news/health-51736185.

[2] Tina Bellon. Empty trains, clogged roads: Americans get behind the wheel to avoid transit. Reuters, 2020. URL https://reut.rs/2yjXn7x.

[3] International Labor Organization (ILO). As job losses escalate, nearly half of global workforce at risk of losing livelihoods. 2020. URL https://www.ilo.org/global/about-the-ilo/newsroom/news/WCMS_743036/lang-en/index.htm.

[4] The Guardian. US unemployment rises by $2.4 \mathrm{~m}$ despite easing of coronavirus lockdowns. 2020. URL https: //www.theguardian.com/business/2020/may/21/us-unemployment-figures-jobs-lost-coronavirus.

[5] Patricia Cohen. Many Jobs May Vanish Forever as Layoffs Mount. The New York Times, 2020. URL https://www.nytimes.com/2020/05/21/business/economy/coronavirus-unemployment-claims.html.

[6] Andy Sumner, Chris Hoy, and Eduardo Ortiz-Juarez. Estimates of the impact of COVID-19 on global poverty. WIDER Working Paper 2020/43. Helsinki: UNU-WIDER, 2020.

[7] World Food Programme (WFP). Chief warns of hunger pandemic as COVID-19 spreads (Statement to UN Security Council). 2020. URL https://www.wfp.org/news/wfp-chief-warns-hunger-pandemic-covid-19spreads-statement-un-security-council.

[8] International Labor Organization (ILO). More than 60 per cent of the world's employed population are in the informal economy. 2018. URL https://www.ilo.org/global/about-the-ilo/newsroom/news/WCMS_627189/lang-en/index.htm.

[9] Marketplace. Food Insecurity Goes Global under the Cloud of Covid-19, year = 2020 . URL https://www.marketplace.org/shows/marketplace-morning-report/food-insecurity-goes-global-underthe-cloud-of-covid-19. 
[10] Corinne Le Quéré, Robert B. Jackson, Matthew W. Jones, Adam J. P. Smith, Sam Abernethy, Robbie M. Andrew, Anthony J. De-Gol, David R. Willis, Yuli Shan, Josep G. Canadell, Pierre Friedlingstein, Felix Creutzig, and Glen P. Peters. Temporary reduction in daily global CO2 emissions during the COVID-19 forced confinement. Nature Climate Change, 10(7):647-653, Jul 2020. ISSN 1758-6798. doi: 10.1038/s41558020-0797-x.

[11] Ishaan Tharoor. The World's Climate Catastrophe Worsens Amid the Pandemic. The Washington Post, 2020. URL https://www.washingtonpost.com/world/2020/06/29/worlds-climate-catastrophe-worsens-amidpandemic/.

[12] Anton Troianovski. A Historic Heat Wave Roasts Siberia. The New York Times, 2020. URL https: //www.nytimes.com/2020/06/25/world/europe/siberia-heat-wave-climate-change.html?referringSource= articleShare.

[13] Shiying Wang and Ge Mengpin. Everything You Need to Know About the Fastest-Growing Source of Global Emissions: Transport. 2019. URL https://www.wri.org/blog/2019/10/everything-you-need-knowabout-fastest-growing-source-global-emissions-transport.

[14] Labor Ministry of Health and Welfare of Japan. Avoid the Three Cs. 2020. URL https://www.mhlw.go.jp/ content/10900000/000619576.pdf.

[15] Taisuke Abiru. How Japan Responded to the COVID-19 Pandemic. 2020. URL https://valdaiclub.com/a/ highlights/how-japan-has-responded-to-covid-19-pandemic/.

[16] Jarret Walker. The Collapse of Rush Hour: A Deep Dive. 2020. URL https://humantransit.org/2020/05/thecollapse-of-rush-hour-a-deep-dive.html.

[17] Soames Job. Can COVID-19 teach us something for the road safety epidemic? 2020. URL https://blogs . worldbank.org/transport/can-covid-19-teach-us-something-road-safety-epidemic.

[18] The Guardian. 'Calamitous': domestic violence set to soar by $20 \%$ during global lockdown. 2020. URL https://ww.theguardian.com/global-development/2020/apr/28/calamitous-domestic-violence-set-tosoar-by-20-during-global-lockdown-coronavirus.

[19] Amanda Taub. A New Covid-19 Crisis: Domestic Abuse Rises Worldwide. The New York Times, 2020. URL https://www.nytimes.com/2020/04/06/world/coronavirus-domestic-violence.html.

[20] Center for Disease Control (CDC). Coping with Stress. 2020. URL https://www.cdc.gov/coronavirus/2019ncov/daily-life-coping/managing-stress-anxiety.html.

[21] Healthline. What COVID-19 Is Doing to Our Mental Health. Healthline, 2020. URL https://www.healthline. com/health-news/what-covid-19-is-doing-to-our-mental-health.

[22] TUMInitiative. COVID19 transmission risks and infection rates in public transport BusTrolleybus - what do we know? 2020. URL https://twitter.com/TUMInitiative/status/1266662574453673985.

[23] Feargus O'Sullivan. In Japan and France, Riding Transit Looks Surprisingly Safe. Bloomberg News, 2020. URL https://www.bloomberg.com/news/articles/2020-06-09/japan-and-france-find-public-transit-seems-safe.

[24] Janette Sadik-Khan. Fear of Public Transit Got Ahead of the Evidence: Many have blamed subways and buses for coronavirus outbreaks, but a growing body of research suggests otherwise. The Atlantic, 2020. URL https://www.theatlantic.com/ideas/archive/2020/06/fear-transit-bad-cities/612979/ ?referringSource=articleShare.

[25] Dennis Normile. Japan ends its Covid-19 State of Emergency. Science Magazine, 2020. URL https://www. sciencemag.org/news/2020/05/japan-ends-its-covid-19-state-emergency.

[26] Nicolas Berrod. "Coronavirus : pourquoi aucun cluster n'a été détecté dans les transports." Le Parisien. 2020. URL https://www.leparisien.fr/societe/coronavirus-pourquoi-aucun-cluster-n-a-ete-detecte-dansles-transports-05-06-2020-8330415.php.

[27] Aaron Gordon. It's Easy, But Wrong, to Blame the Subway for the Coronavirus Pandemic. Motherboard:Thec by vice, 2020. URL https://www.vice.com/amp/en_us/article/qjdy33/its-easy-but-wrong-to-blame-thesubway-for-the-coronavirus-pandemic.

[28] Jeffrey Harris. The Subways Seeded the Massive Coronavirus Epidemic in New York City. 2020. URL http://web.mit.edu/jeffrey/harris/HarrisJE_WP2_COVID19_NYC_13-Apr-2020.pdf.

[29] Alon Levy. The Subway is Probably not Why New York is a Disaster Zone. Pedestrian Observations, 2020. URL https://pedestrianobservations.com/2020/04/15/the-subway-is-probably-not-why-new-york-isa-disaster-zone/.

[30] Salim Furth. Automobiles Seeded the Massive Coronavirus Epidemic in New York City. Market Urbanism, 2020. URL https://marketurbanism.com/2020/04/19/automobiles-seeded-the-massive-coronavirus-epidemicin-new-york-city/. 
[31] Palli Thordarson. The coronavirus is no match for plain, old soap - here's the science behind it. Market Watch, 2020. URL https://www.marketwatch.com/story/deadly-viruses-are-no-match-for-plain-old-soapheres-the-science-behind-it-2020-03-08.

[32] CDC. How Covid Spreads. 2020. URL https://www.cdc.gov/coronavirus/2019-ncov/prevent-getting-sick/ how-covid-spreads.html.

[33] Zeynep Tufecki. We Need to Talk About Ventilation: How is it that six months into a respiratory pandemic, we are still doing so little to mitigate airborne transmission? The Atlantic, 2020. URL https://ww.theatlantic.com/health/archive/2020/07/why-arent-we-talking-moreabout-airborne-transmission/614737/?referringSource=articleShare.

[34] Lucy Craft. Japan has long accepted COVID's airborne spread, and scientists say ventilation is key. $C B S$ News, 2020. URL https://www.cbsnews.com/news/coronavirus-japan-has-long-accepted-covids-airbornespread-and-scientists-say-ventilation-is-key/.

[35] Javier SALAS and MARIANO ZAFRA. Radiografía de tres brotes: así se contagiaron y así podemos evitarlo. El Pais, 2020. URL https://elpais.com/ciencia/2020-06-06/radiografia-de-tres-brotes-asi-secontagiaron-y-asi-podemos-evitarlo.html.

[36] Stephen Benning, Brian Labus, and Kimberly Barchard. To fight coronavirus, here's a trick to stop touching your face so often. Market Watch, 2020. URL https://www.marketwatch.com/story/to-fight-coronavirusheres-how-you-truly-can-stop-touching-your-face-so-often-2020-03-23.

[37] Renyi Zhang, Yixin Li, Annie Zhang, Yuang Wang, and Mario Molina. Identifying airborne transmission as the dominantroute for the spread of COVID-19. Researchgate, 2020. URL https://www.researchgate.net/publication/342128029_Identifying_airborne_transmission_as_the_dominant_ route_for_the_spread_of_COVID-19.

[38] Derek Chu, Elie Akl, Stephanie Duda, Karla Solo, and et al. Physical distancing, face masks, and eye protection to prevent person-to-person transmission of SARS-CoV-2 and COVID-19: a systematic review and meta-analysis. The Lancet, 2020. URL https://ww.thelancet.com/journals/lancet/article/PIIS01406736(20) 31142-9/fulltext.

[39] World Health Organization. Coronavirus disease (COVID-19) advice for the public. 2020. URL https: //www. who.int/emergencies/diseases/novel-coronavirus-2019/advice-for-public.

[40] Elena Polozova. So You're Going Outside: A Physics-Based Coronavirus Infection Risk Estimator for Leaving the House. Medium, 2020. URL https://medium.com/swlh/so-youre-going-outside-a-physics-basedcoronavirus-infection-risk-estimator-for-leaving-the-house-d7dcae2746c0.

[41] Paul Edelstein and Ramakrishnan Lalita. Report on Face Masks for the General Public - An Update. DELVE Addendum MAS-TD1. Published 7 July 2020. DELVE Addendum MAS-TD1, 2020. URL http://rs-delve. github.io/addenda/2020/07/07/masks-update.html.

[42] El Heraldo. Transporte público debe operar a un 35\% de su capacidad: Duque. El Heraldo, 2020. URL https://www. elheraldo.co/colombia/transporte-publico-debe-operar-un-35-de-su-capacidad-duque-719138.

[43] The Guardian. Back to work: capacity of transport network will be down by 90\%. The Guardian, 2020. URL https://www.theguardian.com/world/2020/may/09/back-to-work-capacity-of-transport-networkwill-be-down-by-90.

[44] CDC. Interpretation of Epidemic (Epi) Curves during Ongoing Outbreak Investigations. 2020. URL https: //www.cdc.gov/foodsafety/outbreaks/investigating-outbreaks/epi-curves.html.

[45] Marti Makary. How to Reopen America Safely: Months ago, I called for a long lockdown. Now we must minimize collateral damage. The New York Times, 2020. URL https://www.nytimes.com/2020/05/14/opinion/ reopen-america-coronavirus-lockdown.html?referringSource=articleShare.

[46] Gail Dutton. Multiple Studies Suggest COVID-19 Mortality Rate May Be Lower Than Expected. 2020. URL https://www.pharmalive.com/multiple-studies-suggest-covid-19-mortality-rate-may-be-lowerthan-expected/.

[47] Ministerio de Salud de Colombia. Minsalud amplía al 50\% de ocupación máxima en los sistemas de transporte masivo. 2020. URL https://www.minsalud.gov.co/Paginas/Minsalud-amplia-al-50-de-ocupacion-maxima-enlos-sistemas-de-transporte-masivo.aspx.

[48] Tom Traffic Index. 2020. URL https://www.tomtom.com/en_gb/traffic-index/.

[49] Nikolae Duduta, Claudia Adriazola-Steil, and et al. Traffic Safety on Bus Priority Systems. $E M B A R Q$ - World Bank, 2014. URL https://wrirosscities.org/sites/default/files/Traffic-Safety-Bus-PriorityCorridors-BRT-EMBARQ-World-Resources-Institute.pdf.

[50] Christina Goldbaum. Returning to Work on the Subway? Here's What You Need to Know. The New York Times, 2020. URL https://www.nytimes.com/2020/06/08/nyregion/mta-subway-riding-health-coronavirus. html?referringSource=articleShare. 
[51] World Bank Group. World Bank Group Response to Covid-19. The Transport Sector: A Mobility Crisis. 2020. URL http://pubdocs. worldbank.org/en/375701590520360473/COVID-19-and-Transport-A-Mobility-Crisis.pdf.

[52] Georges Darido and Leonardo Canon. Protecting public transport from the coronavirus... and from financial collapse. Transport for Development, 2020. URL https://blogs.worldbank.org/transport/protectingpublic-transport-coronavirus-and-financial-collapse.

[53] Somini Sengupta and Brad Plumer. How Cities Are Trying to Avert Gridlock After Coronavirus Lockdowns. The New York Times, 2020. URL https://www.nytimes.com/2020/06/26/climate/cities-cars-trafficcongestion. html? referringSource=articleShare.

[54] James Brasuell. NACTO Releases Pandemic Streets Design Guide. Planetizen, 2020.

URL https://www.planetizen.com/node/109418?utm_source=newswire\&utm_medium=email\&utm_campaign=news05282020\&mc_cid=b2ec9d4bd2\&mc_eid=6bed78ad1b.

[55] Justin Gillis and Heather Thompson. Take Back the Streets From the Automobile. The New York Times, 2020. URL https://www.nytimes.com/2020/06/20/opinion/pandemic-automobile-cities.html.

[56] Liz Alderman. Corona Cycleways' Become the New Post-Confinement Commute. The New York Times, 2020. URL https://www.nytimes.com/2020/06/12/business/paris-bicycles-commute-coronavirus. html?referringSource=articleShare.

[57] Deutsche Welle. Pandemia de coronavirus: ¿la oportunidad definitiva para la bicicleta en América Latina? 2020. URL https://www.dw.com/es/pandemia-de-coronavirus-la-oportunidad-definitiva-para-la-bicicletaen-am\%C3\%A9rica-latina/a-53676128.

[58] Mobycon. Making Safe Space for Cycling in 10 Days. 2020. URL https://mobycon.com/wp-content/uploads/ 2020/05/FrKr-Berlin_Guide-EN.pdf.

[59] Thom Bawden. Coronavirus lockdown: Huge demand from the public for more and bigger cycle lanes. inews, 2020. URL https://inews.co.uk/news/coronavirus-lockdown-demand-britons-cycle-lanes-commuting- 433665.

[60] Alcaldia Mayor de Bogota. Encuesta de Movilidad 2019. Indicadores Preliminares, 2019. URL http: //ieu.unal.edu.co/images/Resultados_Preliminares_EncuestaMovilidad_2019.pdf.

[61] Sustainable Mobility for All. Global Mobility Report 2017. Tracking Sector Performance, 2017. URL https://sustainabledevelopment.un.org/content/documents/2643Global_Mobility_Report_2017.pdf.

[62] Karla Dominguez Gonzalez, Ana Luiza Machado, Bianca Bianchi Alves, Veronica Raffo, Sofia Guerrero, and Irene Portabales. Road diets: designing a safer street: Reconfigure traffic lanes and cars will slow down. World Bank, 2020. URL https://elibrary.worldbank.org/doi/abs/10.1596/33466.

[63] Carlos Waters. Road diets: designing a safer street. Vox, 2018. URL https://www.vox.com/2018/7/25/17593344/ road-diets-lane-conversion-traffic-calming-explained-video.

[64] Álvaro Passi-Solar, Paula Margozzini, Andrea Cortinez-O'Ryan, Juan C Muñoz, and Jennifer S Mindell. Nutritional and metabolic benefits associated with active and public transport: Results from the Chilean National Health Survey, ENS 2016-2017. 17:100819, 2020. URL https://www.sciencedirect.com/science/ article/pii/S2214140519301835?via\%3Dihub.

[65] Lisa Weidenfeld. Yes, It's (Probably) Safe to Keep Going on Walks Outside. Boston Magazine, 2020. URL https://www . bostonmagazine.com/news/2020/04/03/walk-outside-coronavirus/.

[66] WSP. Walking and Cycling to Economic Recovery - Lessons. 2020. URL https://www.wsp.com/enAU/insights/walking-and-cycling-to-economic-recovery?deliveryName=DM64561.

[67] Lee Schipper. Transport and CO2 Emissions: A New Framework for a New Challenge. 2009. URL https: //www.mlit.go.jp/kokusai/MEET/documents/MEETFUM/S1-LeeSchipper.pdf.

[68] International Monetary Fund (IMF). Greening the Recovery. Special Series on Policies to Respond to Covid-19. 2020. URL https://www.imf.org/ /media/Files/Publications/covid19-special-notes/en-specialseries-on-covid-19-greening-the-recovery.ashx.

[69] UN News. Post-pandemic 'green shift' in transport could create up to 15 million Jobs. UN News, 2020. URL https://news .un.org/en/story/2020/05/1064382.

[70] Alain Bertaud. Cities as Labor Markets. 2014. URL https://marroninstitute.nyu.edu/uploads/content/ Cities_as_Labor_Markets.pdf.

[71] Thisse J. How Transport Costs Shape the Spatial Pattern of Economic Activity, OECD/ITF Joint Transport Research Centre Discussion Papers, No. 2009/13, OECD Publishing. Paris, 2009. URL https://doi.org/10. $1787 / 5 \mathrm{kmmr} 3 \mathrm{j} 65 \mathrm{tg} 0$-en.

[72] Union Internationale des Transports Publics (UITP). The European exit strategy must include an integrated and sustainable approach to Urban Mobility. 2020. URL https://cms . uitp.org/wp/wp-content/uploads/2020/ 08/Letter_ExitStrategy_must_includeSustainableUrbanMobility.pdf. 
$\Longrightarrow$ Taylor \& Francis Taylor \& Francis Group

http://taylorandfrancis.com 